vulgaris L.) to mechanical stimulation. Z. Pflanzenphysiol 77:437-453

Kahn, B.A., K.E. Conway, and C.G. Fisher. 1986. Effects of wirestem, wind injury, and iprodione on yields of six broccoli cultivars. HortScience21:11361139.

Lamont, W.J. 1993. Plastic mulches for the production of vegetable crops. HortTechnology 3:35-39.

Lanterman, W.S., D.T. Warholic, L.A. Ellerbrock, and P.J. Stachowski. 1985. Effects of fluazifop and barley windbreak competition on seeded onions in organic soil. Proc. Northeastern Weed Sci. Soc. 39:184-187.

Lin, W., J. Ailiang, and Z. Yi. 1987. On the effective protection distance of shelterbelt. Kexue Tangbao (Sci. Rpt.) 32:605-609.

Liptay, A. 1987. Field survival and establishment of tomato transplants of various age and size. Acta Hort. 220:203-209.

Lipton, W.J. 1970a. Growth of tomato plants and fruit production in high humidity and at high temperature. J. Amer. Soc. Hort. Sci. 95: 674-680.

Lipton, W.J. 1970b. Effects of high humidity and solar radiation on temperature and color of tomato fruits. J. Amer. Soc. Hort. Sci. 95: 680-684.

Makus, D.J. 1989. Field-grown European cucumber production-Use of windbreaks and 'mini' cultivars. Proc. Annu. Mtg. Arkansas State Hort. Soc. 109:3539.

Maredia, K.M., S.H. Gage, D.A. Landis, and J.M. Scriber. 1992. Habitat use and patterns by the sevenspotted lady beetle (Coleoptera: Coccinellidae) in a diverse agricultural landscape. Biol.Control 2:159165.

Michailides, T.J. and D.P. Morgan. 1993. Wind scab of french prune: symptomology and predisposition to preharvest and postharvest fungal decay. Plant Dis. 77:90-93.

Miller, D.R., W.T. Bagley, and N. Rosenberg. 1974. Microclimate modification with shelterbelts. J. Soil Water Conserv. 29:41-44.

Monette, S. and K.A. Stewart. 1987. The effect of a windbreak and mulch on the growth and yield of pepper (Capsicum annuum L.). Can. J. Plant Sci. 67:315-320.

NOAA. 1983. Climate atlas of the United States. Natl. Climate Data Center, Asheville, N.C.
Norton, R.L. 1988. Windbreaks: benefits to orchard and vineyard crops. Agr. Ecosystems Environ. 22/ 23:205-213.

Pasek, J.E 1988. Influence of wind and windbreaks on local dispersal of insects. Agr. Ecosystems Environ. 22/23:539-554

Phatak, S.C. 1992. An integrated sustainable vegetable production system. HortScience 27:738-741.

Pohronezhy, K., M. Hewitt, J. Infante, and L. Datnoff. 1992. Wind and wind-generated sand injury as factors in infection of pepper by Xanthomonas campestris pv vesicatoria. Plant Dis. 75:1036-1039.

Rosenberg, N.J., B.L. Blad, and S.B. Verma. 1983. Microclimate: The biological environment. Wiley, New York.

Simons, J.N. 1957. Effects of insecticides and physical barriers on field spread of pepper veinbanding mosaic virus. Phytopathology 47:139-145.

Sturrock, J.W. 1984. Horticulture: wind effects and shelter requirements, p. 53-69 In: Shelter research needs in relation to primary production: The report of the National Shelter Working Party, Wellington, N.Z. 1984. Water Soil Misc. Publ. 59.

Taksdal, G. 1992. Windbreak effects on the carrot crop. Acta Agr. Scand. 42:177-183.

VanGardingen, P. and J. Grace. 1991. Plants and wind. Adv. Bot. Rese. 18:189-253.

Waister, P.D. 1972a. Wind as a limitation on the growth and yield of strawberries. J. Hort. Sci. 47:411418.

Waister, P.D. 1972b. Wind damage in Horticultural Crops. Hort. Abstr. 42:609-615.

Winter, E.J. 1965. Some effects on wind upon vegetable crop plants. Scientia Hort. 17:53-60.

Wells, O.S. and J.B. Loy. 1993. Rowcovers and high tunnels enhance crop production in the northeastern United States. HortTechnology 3:92-95.

Woodruff, N.P., L. Lyles, L. Siddoway, and D.W. Fryrear. 1972. How to control wind erosion. USDAARS, Agr. Info. Bul. 354.

Zachar, D. 1982. Soil erosion. Elsevier, Amsterdam.

Zandstra, B.H. and D.D. Warncke. 1993. Interplanted barley and ryein carrots and onions. HortTechnology 3:214-218.

\section{Stand Establishment in Plasticulture Systems}

\section{Michael D. Orzolek ${ }^{1}$}

Additional index words. transplants, direct seeding, mechanization, plant population

Summary. Plasticulture enables growers to optimize establishment of vegetable and fruit crops under nonoptimum conditions and in locations with short growing seasons. Generally, warm-season crops such as muskmelon, pepper, and tomato, are established from transplants to decrease the time to maturity in the field. Directly seeding vegetables such as sweet corn, cucumber, and snap bean through plastic allows for optimum soil temperature and moisture to ensure maximum seed germination and subsequent seedling emergence. Mechanized transplanting or seeding of vegetables in plasticulture is available and successful if a firm, flat bed with plastic firmly stretched over the bed is formed and specific crop requirements are followed during establishment. Common mistakes made with plant establishment in plasticulture are discussed.

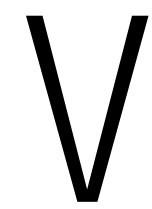
egetable crop production in the northeastern and mid-Atlantic Unites States in the early 1950s generally was limited by extremes in temperatureand moisture. The early efforts of Emery M. Emmert at the Univ. of Kentucky (Jones, 1994) demonstrated that plastic film, whether applied to the soil or covering a stationery structure, dramatically improved crop yields by maintaining more favorable soil temperatures and moisture. Since that early research by Emmert, environmental modification systems

'Department of Horticulture, The Pennsylvania State University.

The cost of publishing this paper was defrayed in part by the payment of page charges. Under postal regulations, this paper therefore must be hereby marked advertisement solely to indicate this fact. 

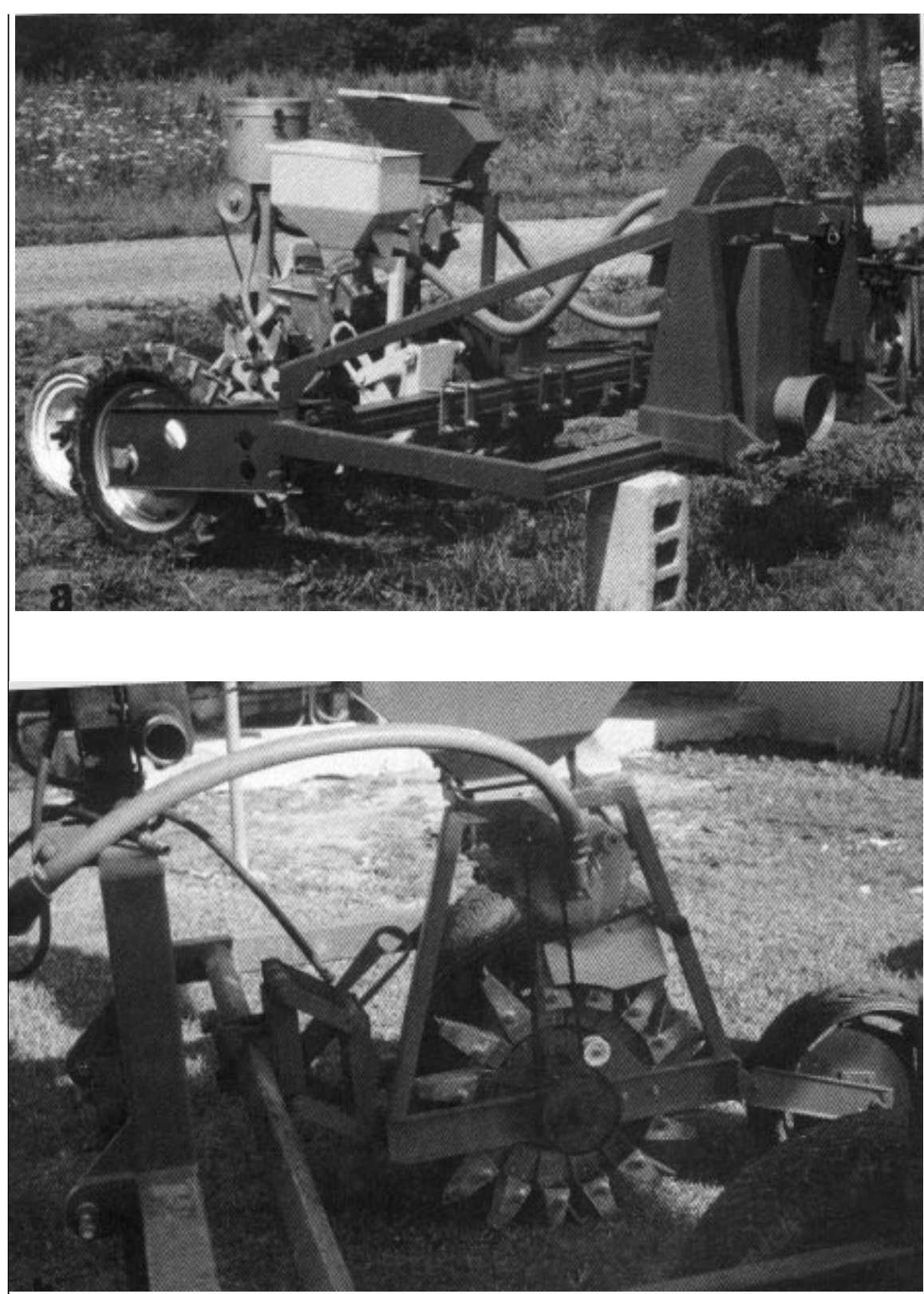

(plasticulture) for vegetable production have been developed including raised beds, drip irrigation, plastic mulch, and plastic tunnels-rowcovers. All of these components of plasticulture contribute to optimization of climatic factors while reducing environmental stress. However, individual components of the plasticulture system can be used alone when establishing vegetables under stressful conditions. Plant establishment in plasticulture systems can be accomplished with either seeds or transplants. The decision to establish a crop by seed or transplant depends on several factors.

\section{Plant establishment}

Optimized crop production in either system depends entirely on successful stand establishment of thecrop being grown (Orzolek, 1991). The big difference between conventional culture and plasticulture is that the area to be planted is distinctly visible in the field, and optimum conditions for growth can be controlled or modified starting with initial establishment. Generally, warm-season crops such as cantal oupe, watermelon, squash, cucumber, tomato, pepper, eggplant, okra, and sweet corn respond with greater plant growth and higher marketableyields in plasticulture. Depending on planting date, growth and yield response of cool-season crops to plasticulture has not been as dramatic as that of warm-season crops.

A primary challenge in establishing vegetables in plastic mulch is the need to perforate the plastic to enable either seed or transplants to be placed in the soil (Shaw, 1987). There are several ways plastic can be perforated: piercing with a sharp edge, punching with ablunt tip, and melting
Fig. 1. (a) The Poly Planter seeder from Ferris Farms, New Cumberland, Pa. (b) This planter perforates the plastic with a stainless steel dibble before placing the seed in the soil through a vacuum, singulation system.

holes with a propane burner. No single perforation method works for all establishment techniques, but choice of perforation method depends on the method of establishment, equipment availability, labor requirement, and cost. In addition, transplant plug size often will determine the size of the hole in the plastic and the easiest method to perforate the plastic. The ability to perforate the plastic mulch also depends on how tight the plastic film is stretched over the bed. If the plastic does not fit the bed tightly, it is difficult to puncture the plastic film.

\section{Transplanting}

Using transplants in plasticulture enables growers to extend the season, double- or triplecrop on plastic mulch, avoid extremes of temperature and moisture, and reduce crop production costs (Shaw et al., 1978). In some locations, it is necessary to establish a crop from transplants to increase the percentage of early-harvested fruit (Ng and Schales, 1978) or reduce the time to harvest of the crop in locations where the number of frost-free growing days is less than 120. Using transplants al so enables growers to producelongmaturing crops such as eggplant in the field in the northeastern United States. Okra transplants have been used during soil solarization in the southern Unites States to generate an income in a lateseason post-plant solarization system(Khan et al., 1993). There are several important factors that determinethe success or failure of transplanting in a plasticulture system.

Transplant quality is one key to successful establishment. Healthy, actively growing plants are more stress resistant and acclimate to environmental conditions when placed in the field, compared to hardened-off, old, pest-infected plants that often have high rates of mortality, even in the production greenhouse. Often transplants are placed in a harsh environment with extremesintemperatureand moisture fluctuation, continual desiccation from wind, and early stress from insects and diseases. Unless these plants receive inputs that diminish the effects of these environmental stresses, plant mortality is inevitable. Water and or fertilizer application through the drip system immediately after transplanting and rowcovers or tunnels can temper the effects of the environment. But even after plants becomesuccessfully established, other problems become evident.

A common problem found in the field after successful crop establishment has been the stem girdling of transplants (i.e., pepper) when air moves under loose plastic and funnels the hot air through the perforated hole with each plant. The need for a very tight fit of the plastic over raised beds be- 
comes self-evident. Uniform plant depth is also important for plant establishment, uniformity of plant development during the growing season, and for a uniform harvest. Plants planted too deep may develop root diseases within weeks after transplanting. Plants that are planted too shallow tend to lodge and be more sensitive to moisture stress.

Crops. Generally, warm-season crops transplanted in plasticulture include tomato, pepper, eggplant, okra, muskmelon, watermelon, slicing cucumber, summer squash, and occasionally iceberg or romainelettuce. For extremely early corn in the northeastern United States, a small acreage is transplanted in plasticulture, which reduces time to maturity by 7 to 10 days. Age of the sweet corn transplant is very important, and the greatest success of sweet corn establishment has been with 17- to 21-day-old transplants. Transplanting peppers in southern United States set to the depth of the cotyledon leaves or the first true leaf reduces heat stress on roots and minimizes fluctuations in soil temperature (Vavrina et al., 1994). In northern climates, setting peppertransplants deep in plasticulture does not produce the same response (Orzolek, unpublished data). Use of transplants in plasticulture generally results in earlier harvests if plants are growing actively when transplanted, more complete and uniform stands, and more options for pest management (Wilson et al., 1993). Several other crops, such as broccoli, cauliflower, pumpkin, and winter squash, can be established as transplants if earliness and reduction in environmental stress are required. Marr and Lamont (1990) suggested using asparagus transplants in plasticulture for establishing this perennial crop with the advantage of earlier and higher potential spear production.

Container cell size. The cell size of the flat used for transplant production can have a direct effect on transplant growth but not on marketable crop yield after establishment in the field. Fisher and Julian (1988) found no difference in total fruit yield from tomato transplants grown in either 400- or 200-cell trays, although therewas a visibledifferencein plant sizefrom plants grown in the two tray cell sizes. Tomato transplants had a higher number of leaves, greater leaf area, larger stems, and higher dry weight when grown in 338cell $(80 \mathrm{~A})$ trays (Speedling Corp., Sun City, Fla.) compared to 200-cell trays (Bennett and Grassbaugh, 1992; Beverly et al., 1992). However, Garton (1992) found that tomato transplants produced in 406-cell trays (TLC Polyform, Plymouth, Minn.) performed just as well as the larger, standard 288-cell trays if established under optimum growing conditions (plasticulture). There was no difference in growth and yield of pepper transplants grown in three different tray sizes: 200 cells (100A, Speedling Corp., Sun City, Fla.) 200 and 288 cells (Landmark Plastics Corp., Akron, Ohio) 7 weeks after transplanting, but there were differences in early pepper transplant growth in the field after transplanting that did not carry through to harvest (Bennett and Grassbaugh, 1995).

Transplant age. Theage of vegetabletransplants depends on crop, variety, climate, transplant vigor, and stress tolerance. A wide range of plant ages will produce acceptable crop yields providing that the plant has not become totally reproductive at time of transplanting into the field. In tomato, for example, transplants from 2 to 13 weeks of age have been established successfully in the field and have produced very acceptable yields; however, the optimum physiological plant age at transplanting for tomato is 4 to 7 weeks (Vavrina and Orzolek, 1993). NeSmith (1994)reported that the transplant age of muskmelon had a significant effect on growth and development of 2-, 4-, 6-, and 8-week-old transplants, but had only a little affect on early and total yields. In fact, the 6and 8-week-old muskmelon transplants began to flower before transplanting in both years. Similar results were obtained with summer squash. Transplants 10 to 35 days old transplants produced similar yields but had different growth rates; younger transplants ( 10 to 21 days old) grew faster than 28- to 35-day-old transplants (NeSmith, 1992). The recommendation for summer squash is 21 days, since any delay in planting would allow for a 10 day window before yield reduction would occur.

Starter solution. Whether to use highphosphorus starter solutions in plasticulture depends on soil temperature at transplanting and how soon after transplanting phosphorus will be applied through fertigation. Research on using starter solutions has been extensive over the last 50 years, but there has been no agreement on crop response and efficacy by researchers. Since the cost of applying a 10-52-10, 12-48-8, or similar analysis fertilizer is relatively low ( $\$ 7.00$ /acre), growers have used high-phosphorus starter solutions as insurance against early phosphorus deficiency symptoms appearing on their crops. In addition, using tray-grown transplants that have been grown under the pretransplant nutritional conditioning system haveall but eliminated phosphorus deficiency in most crops after transplanting in the field.

Mechanization. Manual transplanting on a large scale is labor-intensive, time-consuming, and nonuniform compared to mechanical transplanting. Thevariability in transplant depth during manual transplanting results in nonuniform establishment and growth in the field and, in some instances, results in high transplant mortality. There are several transplanting machines on the market that place plants through the perforated plastic mechanically or require manual setting of

Table 1. The spacing and plant population of several vegetables when transplanted or seeded into plastic mulch on raised beds with drip irrigation.

\begin{tabular}{|c|c|c|c|c|}
\hline Crop & $\begin{array}{l}\text { Within-row } \\
\text { spacing } \\
\text { [inches }(\mathrm{cm})]\end{array}$ & $\begin{array}{c}\text { Number } \\
\text { of } \\
\text { rows }\end{array}$ & $\begin{array}{c}\text { Between-row } \\
\text { spacing [feet }(m)] \\
\text { (center to center) }\end{array}$ & $\begin{array}{c}\text { Plant } \\
\text { population } \\
\text { [plants/acre (ha)] }\end{array}$ \\
\hline \multirow[t]{2}{*}{ Watermelon } & $18(7.1)$ & \multirow[t]{2}{*}{ Single } & $5.0(1.5)$ & $5808(12,778)$ \\
\hline & $30(11.8)$ & & $8.0(2.4)$ & 2269 (4992) \\
\hline Cantaloupe & $24(9.4)$ & Single & $5.0(1.5)$ & 4356 ( 9583) \\
\hline \multirow[t]{2}{*}{ Cucumber } & $8(3.1)$ & \multirow[t]{2}{*}{ Single } & $4.5(1.4)$ & $12,907(28,395)$ \\
\hline & $12(4.7)$ & & $6.0(1.8)$ & $7260(15,972)$ \\
\hline \multirow[t]{2}{*}{ Summer squash } & $24(9.4)$ & \multirow[t]{2}{*}{ Single } & $5.0(1.5)$ & 4356 ( 9583) \\
\hline & 36 (14.2) & & $7.0(2.1)$ & $2074(4563)$ \\
\hline Eggplant & $18(7.1)$ & Single & $4.5(1.4)$ & $7260(15,972)$ \\
\hline \multirow{2}{*}{ Pepper } & $18(7.1)$ & Single & $5.0(1.5)$ & $5808(12,778)$ \\
\hline & $12 \times 16(4.7 \times 6.3)$ & Double & $5.0(1.5)$ & $16,800(36,960)$ \\
\hline Tomato, determ & $18(7.1)$ & Single & $5.0(1.5)$ & $5808(12,778)$ \\
\hline Tomato, indeterm & $30(11.8)$ & Single & $5.0(1.5)$ & 3485 (7667) \\
\hline Tomato,staked & $18(7.1)$ & Single & $5.0(1.5)$ & $5808(12,778)$ \\
\hline Sweet corn & $8 \times 16(3.1 \times 6.3)$ & Double & $5.0(1.5)$ & $25,200(55,440)$ \\
\hline Lettuce, cos & $12 \times 16(4.7 \times 6.3)$ & Double & $5.0(1.5)$ & $16,800(36,960)$ \\
\hline Lettuce, leaf & $8 \times 12(3.1 \times 4.7)$ & Double & $5.0(1.5)$ & $25,200(55,440)$ \\
\hline
\end{tabular}




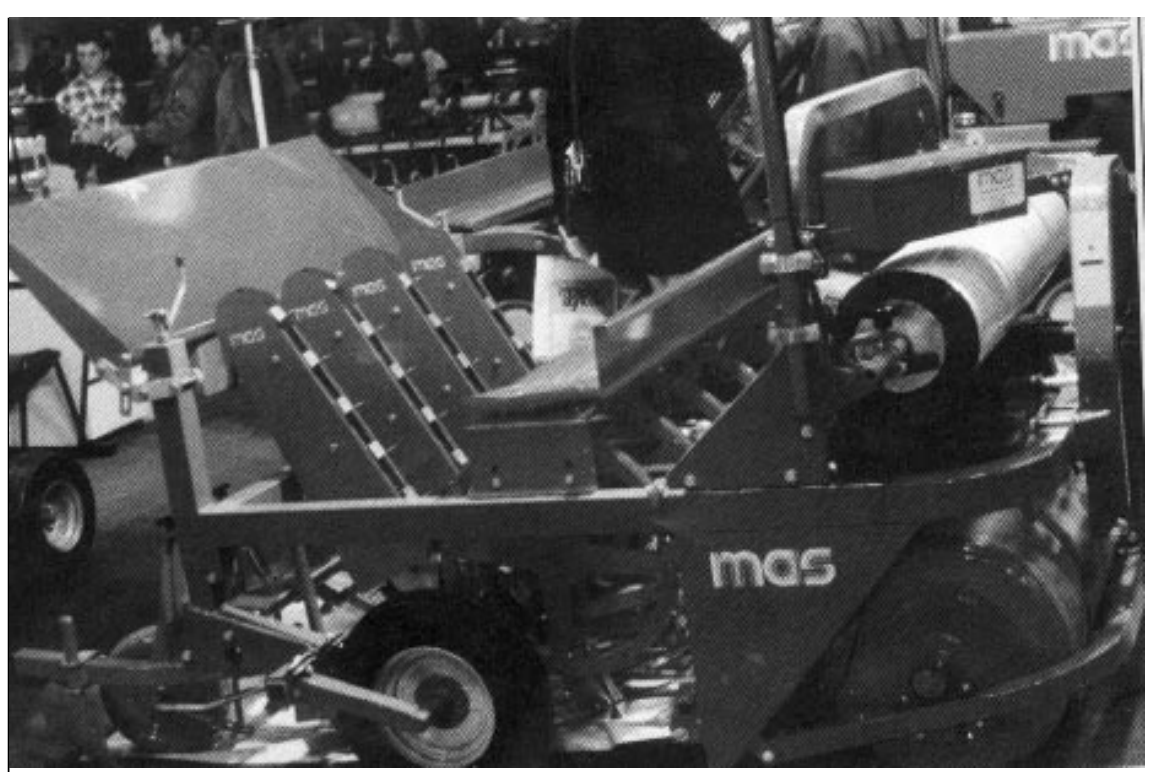

plants into fingers or carousels (Fig. 1). There are only two or three fully automated transplanting systems in use around the world, but none currently is manufactured or available in the United States (Shaw, 1988). The automated mechanical transplanters are expensive, but only require a tractor driver compared to the manual transplanters that require the tractor driver plus two to eight peopleto place transplants through the plastic and firm soil around the plants. In addition, automated transplanters have a high capacity for transplanting in the field (3000 to 4000 plants/h). Many models of transplanters have alarge tank for water or starter solution, which is applied simultaneously or immediately after the transplants have been set in the soil. In addition, a wide range of plant sizes can beplaced in the field depending on the feeding mechanism of thetransplanter (fingers, clamshells, or carousel with drop tube). There are several limitations with these planters. They cannot plant closer than 12 inches in the row; there is a limited tractor operating speed, thus limiting total transplant volumeper day; and it is difficult to transplant under wet soil conditions. Renaldo Sales and Service Inc., North Collins, N.Y., offers the RTM 1100 semi-automatic transplanter for bare ground and plastic mulch. Standard manual transplanters are available from: Holland Transplanter $\mathrm{Co}$., $\mathrm{Hol}$ land, Mich.; Mechanical Transplant Co., Holland, Mich.; Speedling Inc., Sun City, Fla.; and Kennco Mfg., Inc., Ruskin, Fla.

\section{Direct seeding}

Crops. Because high soil temperatures and moisture levels are required for optimum crop production in direct seeding of sweet corn, cucumber, summer squash, and melon, early production is more feasible in northern climates in plasticulture. Since the planting date is 7 to 14 days earlier than planting dates with nonplasticulture systems, conditions following seedling emergence are very critical, since minimum air temperaturecan bebelow optimum threshold temperatures for active growth. Other vegetablecrops that can be sown directly in plastic are snap bean, onion, lettuce, and broccoli. Using primed seeds may be more effective in plasticulture because of possible environmental stresses (temperature, moisture, crusting) to which either seed or seedling may be exposed during the early growth cycle and the seed vigor and uniformity of emergence characteristics of primed seed. Successful direct seeding of vegetable crops in plasticulture is more predictable if the location generally has a long growing season. Transplanted melon crops produced a significantly higher marketable fruit yield than direct-seeded melons in plasticulture (Brown, 1991). tion of any vegetable crop seeded in plastic mulch is determined by the spacing in the row, number of rows per bed, and center-to-center spacingbetween rows. There are some physical restrictions when seeding the crop that limit spacing options: location and placement of the drip irrigation tape in the bed, type of seeding unit available, type of spray applicator used in the field, and size and growth habit of the crop plant. If the drip tape is placed in the center of the bed, then at least two rows can be planted on thebed. If the tape is placed on oneside of the bed, than only one row is planted in the bed. The deeper the placement of the drip tape in the bed, the more precise is the actual location in the finished bed. It is easier to plant multiple rows if tape location is predictable. Because of the physical size of the planter, in somecases, only one unit can beused behind thetractor to plant asinglerow, or, off-centered, two rows can be planted with a double pass over the bed. Depending on the type of sprayer used in making pesticide applications, boom or air blast, between-row spacings may be
Plant population. The final plant popula-
Fig. 2. Transplanter and mulch layer designed by MAS, Candian (Padova), Italy. This semiautomatic transplanting mulching machine first lays plastic and than transplants blocks or plugs at the rate of 7000 to $15,000 \mathrm{plants} / \mathrm{h}$ with one or two operators in the four-row version.

limited. Finally, some plants require more space per unit than others because of size and/or growth habit (eggplant vs. cucumber). Typical plant spacings for direct seeded or transplanted vegetables are given in Table 1.

Double-cropping. Because plasticulture reduces the time to crop maturity, many locations in the United States are able to produce two crops per season per row of plastic mulch. Direct seeding facilitates the planting and emergence of many crops under optimum soil temperatures, and growth is predictable under specific temperature regimes in the field. Double-cropping allows the grower to harvest the first crop in a high market window, removeplant debris from existing mulch rows, and then plant the second crop in themulch, usually by perforating new holes in theplastic and placing the seed in the soil. It is important to keep in mind some of thebasics of integrated pest management, namely, crop rotation, sanitation before planting the second crop, and maintaining pest-free conditions for the first 30 days after planting to enhance crop establishment and early crop development. Knowing the approximate number of days for optimum plant growth (growing season) will enable growers to define crops to be grown for double-cropping and economic viability of the market window. Therefore, growing snap bean after cucumber, broccoli after melon, summer squash after early sweet corn, and other possible crop combinations are recommended, especially in more southern United States. Cleaning the plant debris on the mulchfrom thefirst crop is important to ensure successful establishment of the second crop, reduce physical interferenceduring seeding, reducepest populations, and ensurebreakdown of plant debris. The first crop can be removed either mechanically (mower, flail chopper) or chemically (contact or nonselective herbicides).

Mechanization. Using specialized seeders is critical for successful establishment of a seeded vegetable crop on plastic mulch (Orzolek and Daum, 1984). Most current planters developed for planting vegetable seeds through plastic mulch rely on a piercing mechanism to make the hole in the plastic mulch with a metal dibble, while at the same time individual seeds are placed in the hole. Several types of seed-dispensing mechanisms are available with different planters, but singulation with a precision seeder has been the basic unit for seeding vegetables on plastic covered raised beds (Orzolek and Daum, 1986). Early attempts to seed vegetables directly in plastic mulch resulted in a plug-mix planter in which the vegetable seed was mixed in specific ratios with a 
peat-perlite soilless media to achieve a specific plant population per acre and specific seed number per perforated hole (Hayslip, 1973). The hole was made in the plastic with a propane burner, which left a tear-drop shaped opening in the plastic. This method was successful as long as there was optimum moisture in the peat-perlite mixture to sustain seed germination and emergence. One planter currently used to seed vegetables directly on plastic mulch is the Poly Planter from Ferris Farms, New Wilmington, Pa. (Fig. 2). This planter uses a metal dibble to perforate the plastic mulch, whileat the sametime seeds aresingulated in each perforated holeat a uniform depth. Seed spacing is variable within and between rows so that a large range of plant populations are obtainable.

Themost common mistakes madewith plant establishment in plasticulture are as follows:

1) Lack of afirm, uniformly level bed can lead to air pockets between soil and plastic mulch. If air flows underneath mulch, the hot air funneling through theperforated holes of the plastic mulch can result in stem damage to plants. Producing a firm, level, continuous bed will prevent this problem.

2) Loose plastic over raised bed can result in plant desiccation or death when transplant is covered with the loose plastic mulch. In addition, high winds can lift the plastic mulch off the beds.Calibrating theplastic mulch applicator to put down tight mulch film over the beds before laying film in the field will prevent this problem.

3) Poorly placed drip irrigation tape in the raised bed can result in nonuniform soil moisture levels and nutrient application. If drip tapeis not placed beneath the soil surface in a perfectly straight line, it is difficult to transplant without puncturing thedrip tape. Use of drip tape applicator with hollow chisel placed 2 to 3 inches in the bed will prevent this problem.

4) Failure to operate drip irrigation system immediately after transplanting; especially if soil moisture is less than sixty percent of capacity. Thedrip irrigation system should behooked up and operated before transplanting to prevent this problem.

5) Failure to remove floating row cover or plastic tunnel from a developing crop can result in plant damage or death from excessive heat. Placing thermometers coupled with frequent reading and recording of air temperatures under row cover or tunnels in several locations will help prevent this problem.

6) Failure to calibrate the fertilizer injector or calculate correctly fertilizer rates can result in early seedling and plant damage from excessive salt levels. Calibrate fertilizer injector with known concentrations of N-P-K before transplanting to verify correct operation of the injector. In addition, fertilizer concentrations should be reviewed by cooperative extension agent or irrigation company representatives to prevent this problem.
7) Failure to remove floating row cover or plastic tunnel from a cucurbit crop during flower anthesis to ensureinsect pollination of fruit. Monitoring field of cucurbit crop for flower development at least once a week will help prevent this problem.

\section{Literature Cited}

Bennett, M.A. and E.M. Grassbaugh. 1992. Influence of transplant characteristics on processing tomato seedling development and yields. Proc. Natl. Symp. Stand Establishment of Horticultural Crops, Ft. Myers, Fla. 101:301-310.

Bennett, M.A. and E.M. Grassbaugh. 1995. Cell size and starter fertilizer effects on processing bell pepper transplant growth, crop establishment and yield. Proc. Natl. Symp. Stand Establishment of Horticultural Crops, Monterey, Calif. 4:161-168.

Beverly, R.B., J.G. Latimer, and R.D. Oetting. 1992. Effects of root cell size and brushing on transplant growth and field establishment of 'Sunrise' tomato under aline-source irrigation variable. Proc. Natl. Symp. Stand Establishment of Horticultural Crops, Ft. Myers, Fla. 101:249-258.

Brown, J.E. 1991. Mulches, row covers, and soil solarization for vegetable crops. CRIS report.

Fisher, K.J. and A.P. Julian. 1988. Some effects of delayed planting of tomato cell transplants on later crop performance. Proc. Intl. Symp. Stand Establishment of Horticultural Crops, Lancaster, PA. 1:156-162.

Garton, R.W. 1992. Field performance of 406 cell tomato transplants. Proc. Natl. Symp. Stand Establishment of Horticultural Crops, Ft. Myers, Fla. 101:295-299.

Hayslip, N.C. 1973. Plug-mix seeding developmentsinFlorida. Proc. Fla. StateHort. Soc. 86:179185.

Jones, R.T. 1994. Historical supplement to the Proc. 25th Natl. Agr. Plastics Cong., Lexington, Ky.

Khan, V.A., C. Stevens, J.Y. Lu, D.J. Collins, M.A. Wilson, J.E. Brown, M.K. Kabwe, and O. Adeyeye. 1993. Response of okra transplants grown on soil solarizing plots during the active period of soil solarization. Proc. Natl. Agr. Plastics Congr. 24:162-169.
Marr, C.W. and W.J. Lamont, Jr. 1990. Plastic mulches to establish seedling asparagus transplants. HortScience 25:1661.

NeSmith, D.S. 1992. Transplant age influences establishment and growth of 'Dixie' summer squash. Proc. Natl. Symp. Stand Establishment of Horticultural Crops, Ft. Myers, Fla. 101:265-277.

NeSmith, D.S. 1994. Transplant age has little influence on yield of muskmelon (Cucumis melo L.). HortScience 29:916.

$\mathrm{Ng}$, T.J. and F.D. Schales. 1978. Effect of cultivar, plant density and soil fertility upon yield and quality of muskmel on on blackpolyethylenemulch. Proc. Natl. Agr. Plastics Congr. 14:199-205.

Orzolek, M.D. 1991. Stand establishment of vegetables in the field. HortTechnology. 1:78-81.

Orzolek, M.D and D.R. Daum. 1984. Effect of planting equipment and techniques on seed germination and emergence: a review. J. Seed Tech. 9(2):99-113.

Orzolek, M.D and D.R. Daum. 1986. Planters for seeding vegetables. PennsylvaniaStateUniv., Agr. Eng. Fact Sheet PM-87 p4.

Shaw, L.N., H.H. Bryan, and J.W. Mishoe. 1978. Double cropping mulch covered beds. Proc. Natl. Agr. Plastics Congr. 14:222-226.

Shaw, L.N. 1987. Engineering aspects of crop establishment through plastic mulch. Proc. Natl. Agr. Plastics Congr. 20:232-239.

Shaw, L.N. 1988. A look at automatic transplanting. Proc. Intl. Symp. Stand Establishment of Horticultural Crops, Lancaster, Pa. 1:185-191.

Vavrina, C.S., K.D. Shuler, and P.R. Gilreath. 1994. Evaluating the impact of transplanting depth on bell pepper growth and yield. HortScience 29:1133-1135.

Vavrina, C.S. and M.D. Orzolek. 1993. Tomato transplant age: A review. HortTechnology. 3:313316.

Wilson, M.A., V.A. Khan, and C. Stevens. 1993. Influence of several plastic mulches with four row covers on yield of 'Crimson Sweet' watermelons in southeast Missouri. Proc. Natl. Agr. Plastics Congr. 24:209-214. 